\title{
世界の石油研究所*
}

\section{齊 藤隆**}

(平成 3 年 7 月 1 日受付, 3 年 7 月 17 日受理)

\section{はじめに}

21世紀の国際都市千葉幕張に，関係者多数のご参集を えましたことを，まことに喜ばしく思います。この辺り は，1973年加ら80年にかけて埋立てられた人工造成地で ありますが，今や，で覧になりますように，「幕張メッ セ」とそれに隣接する「千葉マリンスタジアム」を核と しまして，先端的科学技術会社，研究機関，研修施設な どの建設が続けられております。鉄道の整硯が終り，現 在, ホテルの建設が急ピッチで進められている状況であ ります。 3 年後, 5 年後, 千葉幕張は, 筑波研究学園都 市とは趣を異にした, 大規模で活力のあるテクノポリス として, さらに目覚ましい成長, 变貌をとげるるのと思 われます。

この幕張地区の西部の一角に, 当石油開発技術センター は位置しております。1988年11月の施設完成, 翌89年 1 月の開所以来, 約 2 年半が経過致しました。この新研究 所の開設に伴い, 研究開発活動は飛躍的に拡大しその成 果むようやく国際的注目を浴び始めたところであります。 共同研究, 研究委託, 研究員の支流, あるいはセミナ一 等を通して, 石油会社, 石油関連会社, 大学等との協力 関係も深まりつつあります。我々としましては，当セ ンターを日本の石油産業に括けるいわゆる Center of Intelligence (COI) としてこれを位置づけ，またその 名に恥じない上う, 研究開発を中心とした諸活動を積極 的に推進していく所存であります。皆様方のますますの ご支援，ご参加，ご活用をお願い致します。

さて，本日は「世界の石油研究所」と題してお話をさ せていただきます。各研究所の状況を網羅的に調べるの は，むとよりなかなか困難な作業であります。しかし， 研究開発の国際協力が進むにつれて，世界によ゙んな研究

*平成 3 年 5 月 28 日第 56 回石油技術協会定時総会にて特別 講演

**石油公団理事, 石油開発技術センター所長

Copyright (C) 1991, JAPT
所があるのかを知る必要が生じ, また, 国際協力を通じ てその方面の情報むかなり集まるようになりました。そ うした情報む，放っておくとまた散逸し，埋没してしま います。現在のような，情報が集中的に入手できる夕イ ミングに, 不完全ながらあ取りまとめてみようと考えた わけであります。

本日お配りしました資料（簡略化して巻末に添付）は， 石油に関係のある研究所の国別のリストで, 約 3200 研 究所が収録されております。これをもとに，若干の分析 を加えてまいります。

\section{1. 日本の研究所}

日本の石油開発産業といいますか, 石油産業の上流部 門といいますか，この分野の研究所としましては，ご承 知のとおり，帝国石油㧣技術研究所之石油資源開発侏技 術研究所とがあります。

帝国石油㑣技術研究所は，1943年（会社創立の翌々年） に吉祥寺に設置され，その後 59 年に現在と同じ世田谷北 鳥山に移転, さらに84年に会社創立 40 周年記念事業とし て同じ場所に新築されたものです。

石油資源開発㑣技術研究所は，1956年（会社創立の翌 年), 吉祥寺の帝石技研を引き継ぐかたちで設けられ, 74 年に東京西郊の羽村町に新築移転，さらに 88 年 8 月に 幕張に新築移転しました。

両研究所の研究分野のカバレージを比較してみますと 表 1 のうに多少の差異があり，この違いがそれぞれの 特色を示していると思われます。

物理探查技術に関しては, 研究を含めて㑣地球科学総 合研究所 (地科研) が中心的存在となっております。地 科研はまた, 衛星映像の処理・解积もその守備範囲とし ております。衛星映像の分野の中核としては，(期資源観 測解析センター（ERSDAC）があります。

我々の石油開発技術センターの研究開発活動内容につ きましては，来る6月18日から4日間，この同じ場所で 開催されます研究成果報告会に扔いて詳細に行う予定で 
表 1 帝国石油㑣および石油資源開発㑣技術研究所 の研究分野比較

\begin{tabular}{|c|c|c|}
\hline & 帝国石油 & 石油資源 \\
\hline 物探 (震探) 応用技術 & - & \\
\hline 地質構造 & & o \\
\hline 微化石 & $\bullet$ & - \\
\hline 根源岩 (地化学) & 0 & 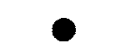 \\
\hline 貯留岩の地質特性 & - & - \\
\hline 䠉留岩の物理特性 & - & - \\
\hline EOR & - & 0 \\
\hline 汃ん水利用技術 $(\exists-ト ゙)$ & 0 & \\
\hline 防食 & - & \\
\hline 天然ガス利用 & - & $\bullet$ \\
\hline 地熱関連技術 & & \\
\hline
\end{tabular}

ございます。組織としては，地質・地化学，物理探査， 油層，開発技術の 4 研究室上り構成されており，10月に は採油増進研究室（仮称）を新たに発足させて 5 研究室 体制と致します。研究分野としては，微化石，衛星眏像， 地熱等は, 現在カバーしておりません。

関連の研究機関として, (的)新エネルギ一開発機構 (NEDO)，工業技術院地質調查所等があります。

参考までに，下流部門に目を転じてみますと，日本石 油侏中央技術研究所, 東燃㑣総合研究所, 昭和シェル石 油侏决央技術研究所, 出光與産(㑣)中央技術研究所, 三菱 石油㑣研究本部，興严石油(保大阪研究所，ゼネラル石油
(侏中央技術研究所，また会社組織となっているすのとし て俰コスモ総合研究所，侏共同製品技術研究所がありま す。また，財石油産業技術研究所が，千葉市東部の土気 に建設を予定しております。

\section{2. 米国系メジャーズの研究所}

米国系メジャーズは，ガルフがシェブロンに吸收合併 されましたので，現在次の 4 社であります。

Exxon Corp. (New York)

Chevron Corp. (San Francisco)

Texaco Inc. (White Plains, N. Y.)

Mobil Corp. (New York)

エクッン・グループの構成は次のごとくて，上流・下 流の研究部門はともに会社組織となっております。

Exxon Corp.

Exxon Co. USA

Imperial Oil Led.

Exxon International Co.

Esso Chemical Co.

Exxon Minerals Co.

$\rightarrow$ Exxon Production Research Co.

$\rightarrow$ Exxon Research \& Engineering Co.

Exxon Enterprises Inc.

上流部門の研究会社が Exxon Production Research Co.(EPR) で，ヒューストンにあり，研究開発の1つ の牙城となっていますが, 秘密性が強く，研究者の管理

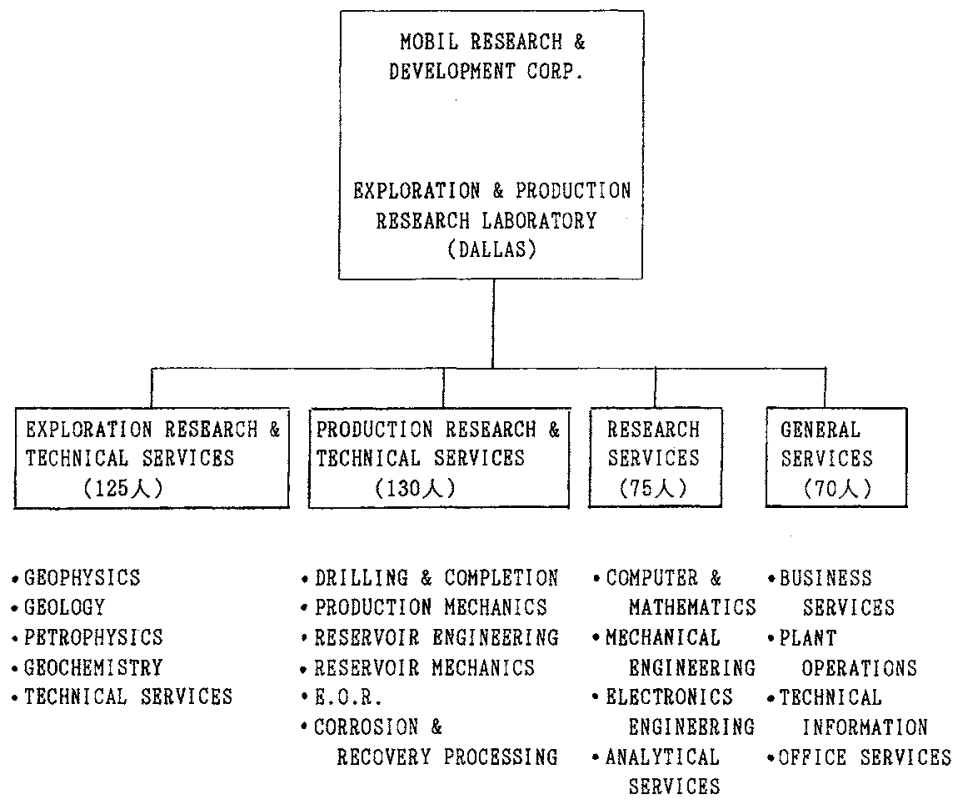

図 1 モービル上流部門研究所の組織概図 
す厳しいと言われております。

シェブロンの研究部門(上流) 丢社組織で, Chevron Oil Field Research Co. と呼ばれ，ロサンゼルス郊 外のラハブラにあります。テキサコの研究部門（上流） は Texaco Houston Research Centerで, ヒュース トンにあります。

米国系メジャーズの研究部門の例として, モービルに ついて少し分析してみましょう。モービルというのは, 持株会社であるMobil Corp. を頂点とし, 多数の構 成会社を㖓下にすつ企業集団です。構成会社の中心をな すのが Mobil Oil Corp. で, その研究部門は Mobil Research \& Development Corp. です。2つの研 究所を持ち, 上流が Exploration \& Production Research Laboratory (ダラス, 400 人), 下流が Paulsboro Laboratory (ニュージャージー, 1,200人) です。上流の研究所の組織系統は図 1 の上うに示されま す。

米国系，欧州系をとわず，メジャ一ズは複数の研究所 を有し, 上流部門と下流部門とは分かれていて, 研究者 の数の上で下流の研究所の方が数倍の大きさとなってい ます。この状況は, Royal Dutch/Shell グループの 米国子会社である Shell Oil Co. の場合も同様で，上 流の研究所はヒューストンにあって700人, 下流の研究 所はミドランドにあって 1,300 人の規模であります。

\section{3. 米国系インディペンデントの研究所}

米国系インディペンデントの石油会社としては，アモ コ，アーコ，オキシデンタル，マラソン，コノコ等々多 数あります。ここでは 1 つ例としてュノカルをとり上 げてみます。

ュノカルというのは, 持株会社 Unocal Corp. を頂

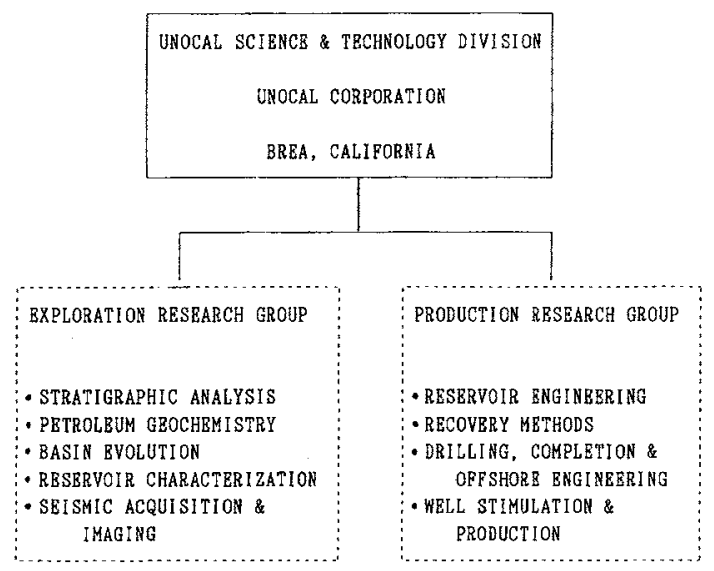

図 2 ユノカル研究所上流部門の組織概図
点とする企業集団ですが，その研究部門は，Unocal Corp. 直属のいわば研究本部のような形の Unocal Science \& Technology Division という組織で, 口 サンゼルス郊外のブレアというところにあります。上流 下流が同じ敷地内に研究所を持つ点ではメジャーズと異 なりますが, 研究者の人数については，全体で 1,000 人 のうち上流が 4 分の 1 の 240 人で, 上・下流の人数比は メジャーズの傾向と変わりません。上流の研究組織系統 は図 2 のごとくです。

\section{4. 欧州系メジャーズの研究所}

欧州系メジャーズは次の 3 社（グループ）です。

Royal Dutch/Shell Group (The Hague,

London)

British Petroleum Co. p.1.c. (London)

Total-CFP (Paris)

ロイヤル・ダッチ・シェル・グループは, 米国子会社, カナダ子会社, 昭和シェル石油保などのあのを含めて世 界中に14の研究所を持っていますが，それらのうち中核 となっているのは次の 4 つです。

$\rightarrow \mathrm{KSEPL}$ (探鉱・開発)

KSLA （精製・石油化学）

STL （マーケティング）

SSL （農業用等のケミカル）

上流の KSEPL の組織系統は図 3 のごとくです。

BP あ同様にいくつかの研究所を持っており，その 中で上流部門のものはロンドン郊外にある Sunburry Research Centreであります。

Total-CFP は 4 研究所を持ち, 上流関係はPessac Laboratory (探鉱) と Beauplan Laboratory（掘 削, 生産) の 2 つです。

\section{5. 先進国国営会社の研究所}

先進国国営石油会社の代表的なすのとして，フランス のSNEA（エルファキテーヌ)，イタリアのENI，をれ に，これは民営化の途上にありますが，カナダの PetroCanada があげられます。

SNEA は, ご承知のとおり, パりのエルフ社とポー のアキテーヌ社とが合併してできた会社で本社はパリ西 部の新副都心ラデファンスの中にそそり立っていますが, フランス南部のアキテーヌ地方のポー事務所むなかなか 立派なもので，ここが同社の技術拠点亡なっております。 ここから少し離れたところに, Jean Fëger Research Center 亡, 自慢の研修施設である Andre Bouillot International Training Center とがあります。 イタリアのENIは，石油を中心として幅広い活動分 


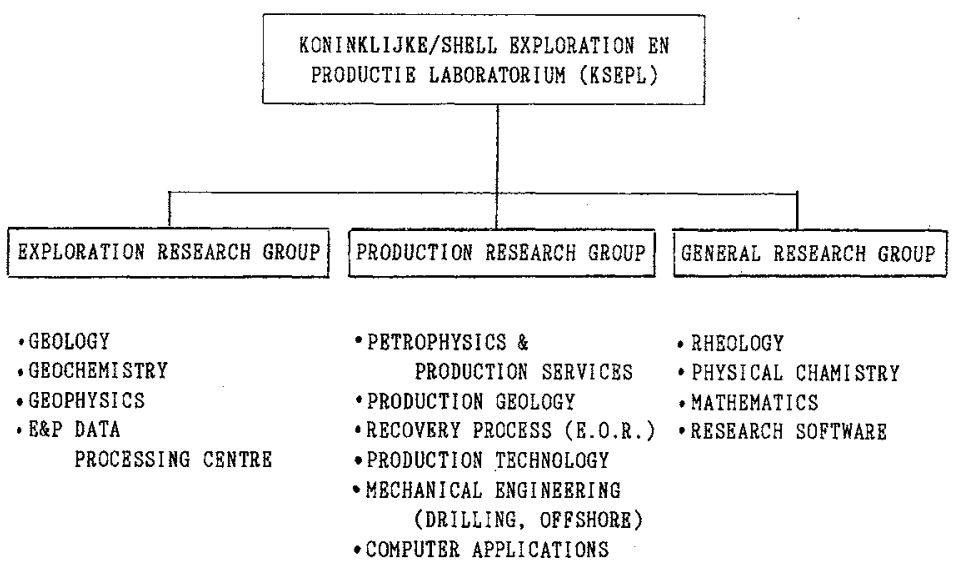

図 3 ロイヤル・ダッチ・シェル・グループ上流部門研究所（KSEPL）の組織概図

野を屯つ企業集団ですが，その研究部門は Eniricerche と称し，会社組織となっておりましてミラノにあります。 Eniricercheは, 広範囲の研究分野にわたり積極的に活 動を行っている研究機関として注目されます。

カナダの Petro-Canada の研究所としては, Exploration Research \& Development Laboratory (探鉱部閒) と Production Research \& Development Laboratory (生産部門) とがあり，いずりも力 ルガリ大学の近くに置かれております。

\section{6. 独立した石油専門の研究所}

石油産業とのつながりはあちろん極めて強く持ちつつ 屯, 特定の石油会社の英下にはない, 独立した研究所と
して, フランスのIFP，インドネシアのLEMIGAS, カナダの PRI，英国の Petroleum Science \& Technology Institute，米国の NIPER 等があります。小 規模のものを含めると，この範ちゅうのものは他にも多 数あります。これらのうち IFPについて少し掘り下げ てみます。

IFPすなわち Institut Francais du Petrole は, パリの南のマルメゾンという自然に恵まれた素晴らしい 環境の中にあります。トレーニングや技術者派連などを 含めて，活動範囲は多様ですが，研究開発に限ってその 組織系統を単純化して描いてみると次のようになります。 これは上流, 下流部門之, 共通のコンピュー夕, 数学, デー夕姏理部門とに大別できます。なお，IFPの研究

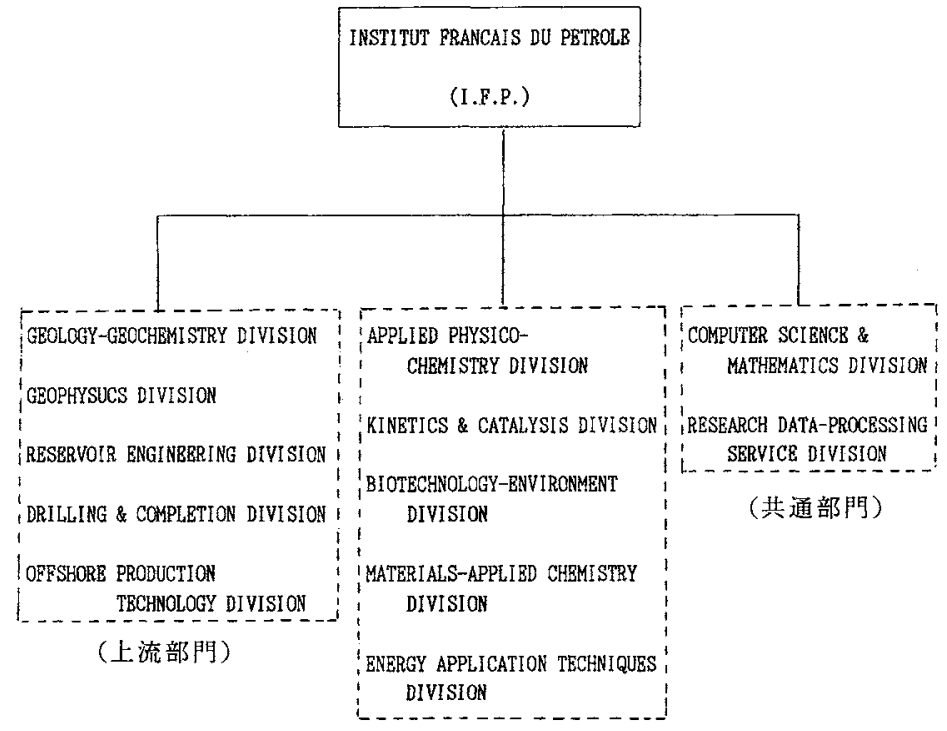

(下流部門)

図 4 IFP の研究開発部門の組織概図 
部門の長は, 有機地化学, 根源岩評価技術の体系化，分 析装置 Rock-Eval の普及などで日本ですよく知られ ている Tissot 博士であります。

\section{7. 発展途上国国営石油会社の研究所}

発展途上の大産油国あるいは中産油国の国営石油会社 あ，それぞれにかなりの規模の研究所を持っております。 学術雑誌なぞに先端的論文を発表することが少ないなど の理由で，その存在は目立ちませんが，拡充がはかられ ており，看過できません。アジアの例を $2 つ$ づます。

まず，インドの国営会社は ONGCですが，挆鋐関係 2(うち1つはデー夕処理センター)，油層関係と掘削関 係各 1 , 計 4 つの研究所を持っております。ONGC は, 海洋のボンベイハイ油田の発見, 開発, 生産操業を通し てカをつけ，今や日産60万バレルの大会社に成長しまし たが，この力を背景として広範囲の研究活動を展開して 抢ります。当石油開発技術センターとは, 施設の規模に おいてす，研究者の数においてす比較にならない大きさ であることを申し上げておきます。最近欧米の石油研究 所においてインド人の活躍が目をひくのも，自国に石油 技術というあのが完全に根づいた現れと見ることができ るかす知れません。

あう 1 つの例は, マレーシアの国営会社 Petronas で す。現在のマレーシアの石油産業は, 1976年にシェル, エクンンとの戦いの末に, 利権契約をコンセッション方 式からPS方式に改めたところから始まり，外国企業に 頼らず自ら操業することを悲願としてきたと言えましょ うが, 近年自らの研究所である Petroleum Research Institute（PRI）を創設し，この方面でも理想に向かっ
て着実に歩んでいるように見受けられます。

最近, 国営会社が研究所を持つという傾向が強まって いるようでありまして，実は先週アブダビ ADNOC の 探鉱，開発の責任者の Rashid Al-Suwaidi 氏が来日 し，当技術センターにあお見えになりましたが，油価が 今少し上昇したら，加称て念願の研究所建設を実現した いとあらしておられました。その暁には，研究所を開設 するためのノウハウを提供してほしいとの意思表示むあ りました。インドネシアのプルタミナ禾研究所建設を計 画していると，昨年来訪された Nayoan 氏，Naim 氏 あおっしゃっておりました。アフリカの国々からも研 究所建設に関する協力要請が来ております。

\section{8. 特殊な専門分野の研究所}

専門分野の特化したものとして, 衛星映像関係では才 ランダのITC, 米国の USGS-EROS Data Center, 日本の ERSDAC，中国の国立摆感中心などがあります。

重質油関係では, カナダのAOSTRA，PRIなどが ありますが,この関係の研究所は最近かなり多く新設さ れてきております。

物理㭘層請負のシュルンベルジェ社は, フランスのク ラマン, 米国東部のリッジフィールドと南部の七ュース トン，英国のケンブリッジに中核的研究所を配置し，ま た神奈川旉の洲野辺にあるシュルンベルジェ㑣む一部の 研究開発に寄与しております。

\section{9. 中国の研究所}

中国の陸上に打ける石油探鉱，油田開発，原油生産・ 輸送を行っているのが中国石油天然気総公司（CNPC）
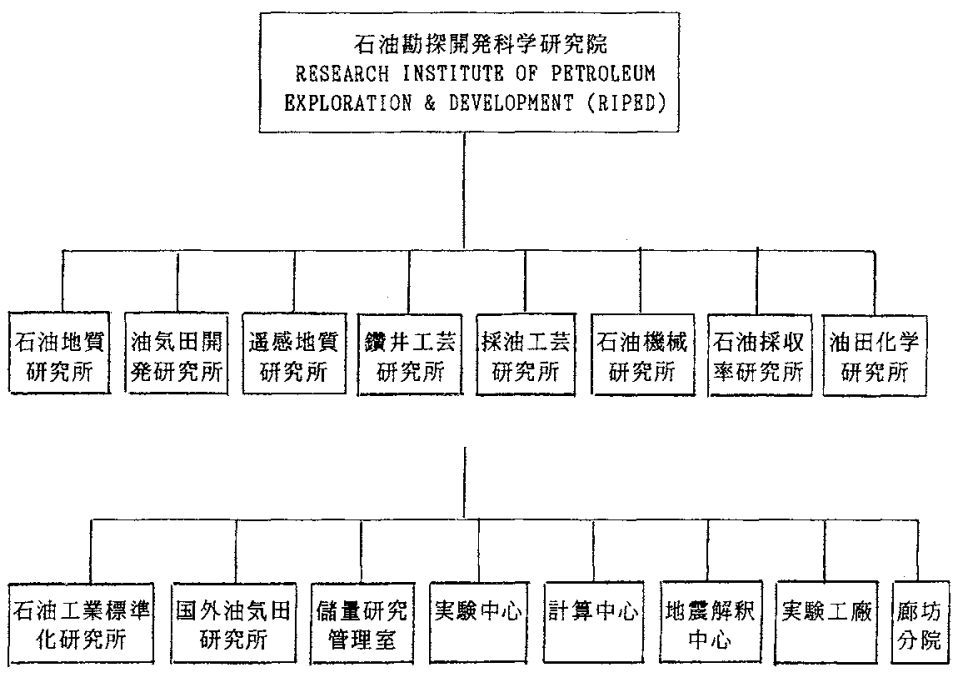

図 5 中国石油勘探開発科学研究院の組織概図 
であり，その研究部門の最重要の研究所は石油勘探開発 科学研究院（RIPED）と呼ばれるものであります。こ れは北京市内にあり, 従業員 2,700 人, 内研究員 1,000 人という大規模なものです。これはアジアでも有数の石 油研究所と言えるでしょう。その組織系統は図 5 のごと くです。

また海上を担当する中国海洋石油総公司 (CNOOC) の研究所は, 海洋石油勘探開発研究中心 (EDRC) 之 呼ばれ，北京の南，車で約 2 時間半の河北省新城県とい うところにあります。これは1986年に設立された新しい 研究所で，外国製の最新の機器類が導入されておりま 于े。

\section{0. 研究所情報の整理}

以上説明してまいりました内容のバックデータとし て，私どもでは石油研究所個表（表 2) に記入すること により情報を整理しております。必須の記入項目とし て, 研究所名, アドレス, 電話等の番号, 主要人物, 特 雊，組織系統を設けております。個表は 2 枚目から空欄 とし，自由に記入できるようにしてあります。本日お配 りしました資料は，研究所名，アドレスのみを，国別に 列記してすのです。皆様のご協力により，これをさらに 充実させ，後日再びお配りしたいものと考えておりま 于。

表 2 研究所情報を整理するための個表

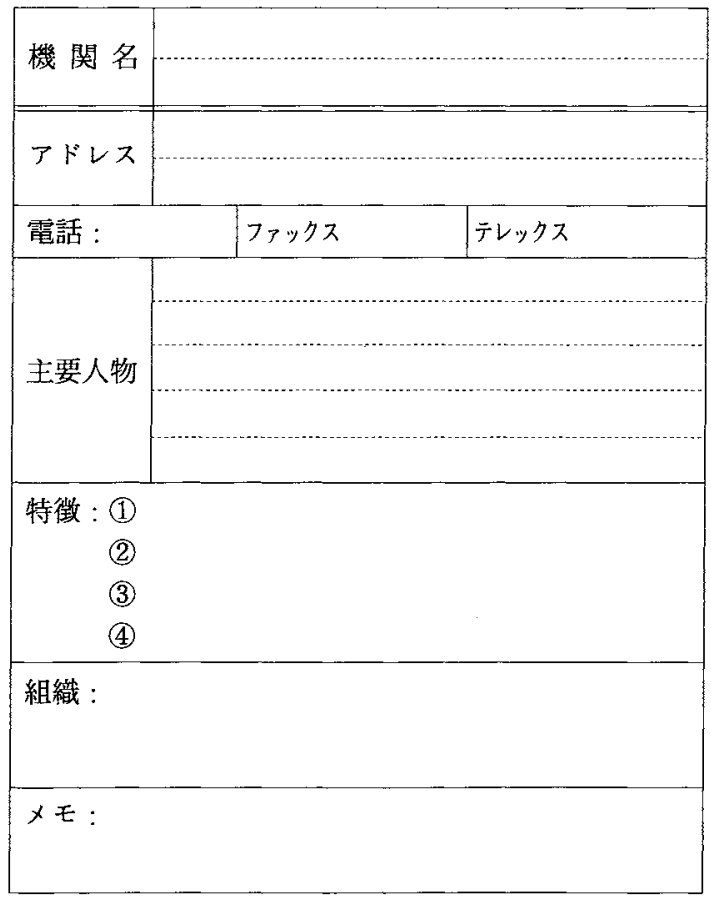

\section{1. 最近の研究の傾向}

最近，これは石油の探鉱・開発技術に限らぬ一般的な 傾向と思われますが，1つの大学等の研究所を核とした 研究コンソーシアムの形成あるいは本来競争相手である べき 2〜3の研究所が共同研究契約を結びそれぞれの得 意の技術分野を分担する方式が，頻繁に出現するように なりました。我々の石油開発技術センターに対しても， 参加の誘い, 当方の研究への参加の打診などが目立ちま क。

このような傾向の理由として，低油価の状況下におい て研究開発予算が少なくなっていること, 研究スピード が加速化していること，従来の石油会社にはなかった分 野の先端技術者の力を必要としつつあこれを 1 研究所で 抱えることは困難であること，などがあげられます。

其同研究という一種の分業化の中で，それでは日本は どんな役割を担えるのか，また担うべきなのか，という 問いかけにこのところよく接します。日本の先端技術と いえば，エレクトロニクス，素材技術，精密工作技術， 工程管理技術などがすぐに思い浮かびます。これらは， 石油の探鉱・開発においてお，機器開発の面で大いに役 立つあのであります。立ち遅れているといわれるソフト 面については，古ろん地道な研究活動を継続するかた わら，これは私見ですが，研究のための「場」を広く提 供していく努力あ必要であり，有効であると思います。 例えば内外の大学研究者に門戸を開く，处国の第一線の 研究者に日本で働いてもらう，そうしたことを念頭に揖 きつつ，いろいろな意味での研究環境というものを整備・ 充実して参りたいと思います。最後に，研究所情報を提 供して下さった多くの方々, とりまとめに協力して下さっ た方々に礼を申し上げて，私の話を終わらせていただ きます。有難うございました。

\section{世界の石油関連研究機関一覧}

\section{ALGERIA}

Societe National pour la Recherch, la Production, le Transformation et al Commericialisation des Hydrocarbones (SONATRACH)-Centre de Recherches et de Development

\section{ANGOLA}

Sociedade Nacional de Combustiveis de Angola Exploration, Production Laboratories Center

ARGENTINA

Institute Argentino de Ingenieria S.R.L.

Yacimentos Petroligeros Fiscales (YPF) - Research Center

AUSTRALIA

Australian Institute of Energy 
Bureau of Mineral Resources (BMR)

Geological Survey of Queensland

Geological Survey of South Australia

Geological Survey of Victoria

Geological Survey of Western Australia

Institute of Energy \& Earth Resources

(of Commonwealth Scientific \& Industrial Research Organisation (CSIRO))

\section{BELGIUM}

Labofina (Centre de Recherches du Groupe Petrofina)

\section{BOLIVIA}

Servicio Geologico de Bolivia

BRAZIL

Instituto Brasileiro de Petroleo

\section{BULGARIA}

Bulgarian Academy of Sciences-Institute of Geo$\log y$

CANADA

Alberta Energy Resources Conservation Board Core Research Center

Alberta Oil Sands Technology \& Research Authority (AOSTRA)

Alberta Research Council

Canadian Energy Research Institute

Geological Survey of Canada

Geological Survey of Canada - Institute of Sedimentology \& Petroleum Geology

Geological Survey of Canada - Atlantic Geoscience Centre

Geofuel Research Inc.

Nova Husky Research Corporation Ltd.

Ontario Petroleum Institute

Petro-Canada-Exploration Research \& Development Laboratory

Petro-Canada-Production Research \& Development Laboratory

Petroleum Recovery Institute (PRI)

Saskachewan Research Council

Shell Canada Ltd. - Calgary Research Centre (oil and gas exploration and Production)

\section{CHILE}

Servicio Nacional de Geologia y Mineria

CHINA

Ministry of Geology \& Mineral Resources 地質硡 産部

一石油地質海洋地質局北京計算中心

一石油地質海洋地質局石油物探研究所

一石油地質海洋地質局石油地質実験中心

一石油地質海洋地質局総合研究所

一石油地質海洋地質局試錐研究所

一地質科学研究所

一石油地質研究所

一勘探技術研究所

一地質遥感中心

一華東石油地質局総合研究中心

一瀋陽地質鉱産研究所

- 西安地質鉞産研究所

一宜昌地質鉱産研究所
China National Petroleum Corporation (CNPC) 中国石油天然気総公司

一石油勘探開発科学研究院

一石油地球物理勘探局解彩中心

- 石油地球物理勘探局研究院

一西北石油地質勘探研究院

一石油工程技術研究所

- 大慶科学研究規画院

China National Offshore Oil Corp. (CNOOC) 中国 海洋石油総公司

一海洋石油勘探開発研究院

一渤海石油公司研究院

一南海石油公司研究院

Chinese Academy of Sciences 中国科学院

一広州能源研究市

一地質研究所

- 地球物理研究所

一海洋研究所

- 南海海洋研究可

一南京地質古生物研究所

Chinese Academy of Geological Sciences 中国地質 科学院

一天津地質鉱産研究所

State Seismological Bureau 国家地震局

- Institute of Geophysics

National Remote Sensing Center

COSTA RICA

Colegio de Geologos de Costa Rica

CZECHOSLOVAKIA

GEOINDUSTRIA, n. p.

DENMARK

Danmarks Geologiske Undersogelse(DGU)(Geological Survey of Denmark)

Forskningscenter RISO (RISO National Laboratory)

Danmarks Tekniske Hojskole (DTH) (The Technical University of Denmark)

Greenland Geological Survey

DJIBOUTI

Institut Superieur d'Etudes et des Recherches Scientifiques et Techniques

\section{EGYPT}

Egyptian General Petroleum Corp - Institute of Petroleum Research

EL SALVADOR

Centro de Investigaciones Geotecnicas

FRANCE

Total-CFP Pessac Laboratory (Laboratories Exploration)

Total-CFP Beauplan Laboratory (Laboratories Drilling/Production)

Total-CFP Certed Laboratory (Laboratories Alternative Energy)

Total-CFP Gonfreville Laboratory (Laboratories Refining/Petrochemicals)

Institut Francais du Petrole (IFP)

Societe Nationale Elf-Aquitaine (SNEA) -Les Centres Recherche en Exploration, Production

Bureau d'Etudes Industrielles et de Cooperation 
de I'Institut de Petroloe (BEICIP)

Bureau de Recherches Geologiques et Miniers

Etudes-Production Schlumberger

GERMANY

Bundesanstalt fur Geowissenchaften und Rohstoffe

Federal Institute for Geosciences and Natural Resources

Institute of Petroleum Organic Geochemistry

Institute of Oil Research

German Company for Mineral Sciences \& Coal Chemical (DGMK)

National Facilities for Geosciences \& Natural Resources

Deutche Geophysische Gesellshaft (DGG)

Kernforschungsanlage Julich $\mathrm{GmbH}$ (KFA)

GUATEMALA

Divisao de Geologica - Instituto Geografico Militar

HUNGARY

Hungarian Hydrocarbon Institute

INDIA

Geological Survey of India

Indian Institute of Petroleum

Oil \& Natural Gas Commission (ONGC) - Institute of Petroleum Exploration

Oil \& Natural Gas Commission (ONGC) - Geodata Processing Centre (GEOPIC)

Oil \& Natural Gas Commission (ONGC) - Institute of Reservoir Studies

Oil \& Natural Gas Commission (ONGC) - Institute of Drilling Technology

INDONESIA

LEMIGAS (R \& D Centre for Oil \& Gas Technology)

Geological Research \& Development Centre

Marine Geological Institute of Indonesia (MGI)

Research \& Development Centre for Geotechnology (RDCG) (of The Indonesian Institute of Sciences)

IRAN

National Iranian Oil Co. - Research Institute of Petroleum Industry

\section{IRELAND}

Geological Survey of Ireland

ISRAEL

Institute of Petroleum Research \& Geophysics

ITALY

ENIRICHRCHE

AGIP - Exploration \& Production Laboratories Servizio Geologico d'Italia

JAPAN

Geological Survey of Japan 地質調査所

Japan National Oil Corporation (JNOC)

Technology Research Center 石油公団石油開発技 術センター

Teikoku Oil Co. - Technical Research Center 帝国 石油媒技術研究所

JAPEX Research Center 石油資源開発侏技術研究所 Japex Geoscience Institute Inc. (JGI) (制地球科学総
合研究所

National Institute of Polar Research 国立極地研究 所

New Energy Development Organization (NEDO) (財)新エネルギー開発機構

Earth Resources Satellite Data Analysis Center (ERSDAC) 期資源観測解析センター

Institute of Energy Economics, Japan 日本エネル ギー経済研究所

Nippon Oil Co., Ltd. - Central Technical Research Laboratory 日本石油(侏)中央技術研究所

Tonen Corporation-Corporate Research \& Development Laboratory 東燃侏総合研究所

Cosmo Research Institute(㧣 コスモ総合研究所

Showa Shell Sekiyu K.K. - Central Research \& Development Laboratory 昭和シェル石油(株中央研 究所

Idemitsu Kosan Co., Ltd. - Central Research Laboratories 出光興産(秼中央研究所

Mitsubishi Oil Co., Ltd. - Research Headquarters 三菱石油(秼研究本部

Koa Oil Co., Ltd. - Osaka Research Laboratory 與重石油(株大阪研究所

General Sekiyu K. K.-Central Research Laboratory ゼネラル石油(株中央研究所

Kyodo Oil Technical Research Center Co., Ltd. (株)共同製品技術研究所

Petroleum Industry Technology and Research Institute, Inc. 搳石油産業技術研究所

KOREA

Korea Institute of Energy and Resources (KIER)

MALAYSIA

Geological Survey of Malaysia

Petroleum Research Institute (PRI)

MEXICO

Consejo de Recursos Minerales

Mexican Petroleum Institute

MONGOLIA

Institute of Geology \& Natural Reseources

MYANMAR

Myanma Oil \& Gas Enterprise (MOGE) - Exploration Research Laboratories

NETHERLANDS

International Institute for Aerial Survey and Earth Sciences (ITC)

Koninklijke/Shell Exploratie en Produktie Laborarium (KSEPL)

Koninklijke/Shell Laboratorium (basic research)

Rijks Geologische Dienst (Geological Survey of the Netherlands)

NEW ZEALAND

New Zealand Geological Survey

NORWAY

Norks Hydro a. s. - Bergen Research Centre

IKU (Continental Shelf Institute)

Institutt for Energietecknikk

Rogaland Research Institute (Rogalands Forskning)

Seismic Research \& Development a. s. 
Undersokelses og Produksjons Laboratoriet

\section{PAKISTAN}

Geological Survey of Pakistan

Hydrocarbon Development Institute of Pakistan (HDIP)

\section{PHILIPPINES}

Bureau of Energy Department

Bureau of Mines \& Geo-Sciences

\section{SAUDI ARABIA}

Saudi Arabian Oil Company ("Saudi Aramco") - Research \& Engineering Centre

King Fahd University of Petroleum \& Minerals Research Institute

\section{SPAIN}

Instituto Geologico y Minero de Espana (Spanish Geological \& Mining Institute)

\section{SUDAN}

Geological Research Authority of Sudan

Geological Survey of Sudan

\section{SWEDEN}

Geological Survey of Sweden

Swedish Petroleum Institute

\section{SWITZERLAND}

Geologisches Institut ETH

\section{TURKEY}

Turkish Petroleum Corporation (TPAO) - Research Center

\section{UNITED KINGDOM}

British Geological Survey

British Petroleum - Sunbury Reseacrch Centre (SRC)

Intera-ECL Petroleum Technologies

Institute of Energy

Institute of Petroleum (IP)

The Petroleum Science and Technology Institute

Robertson Group plc.

Newcastle Research Group (NRG) in Fossil Fuels \& Environmental Geochemistry

Schlumberger Cambridge Research

Tectosat Exploration System N. V.

U. S. A.

Alaska Division of Geological and Geophysical Survey

Amoco Chemical Co. - Amoco Research Center

Amoco Oil Co.-Amoco Research Center

Amoco Production Co. - Research Center

Arizona Geological Survey

ARCO Oil and Gas Co.-Exploration \& Technology

ARCO Resources Technology -Exploration \& Production Research

Arctic Environmental Information and Data Center (AEIDC)

Arkansas Geological Commission

Board of Earth Sciences, National Research Council
Byrd Poar Research Center (of The Ohio State University)

Chevron Oil Field Research Co.

Colorado Geological Survey

Connecticut Geological \& Natural History Survey

Conoco Exploration Research \& Development

Core Laboratories Inc.

DeGolyer and MacNaughton

Delaware Geolgical Survey

DOE-Pittsburgh Energy Technology Center

DOE-Morgantown Energy Technology Center

Earth Resources Institute

East-West Center - East-West Resources System Institute

Exxon Production Research Co.

Exxon Research \& Engineering Co.

Florida Geological Survey

Geochemical \& Environmental Research Group (GERG)

Gelogical Survbey of Alabama

Georgia Geological Survey

Horn Pint Environmental Laboratories

Idaho Geological Survey

Illinois Geological Survey

Indiana Geological Survey

Iowa Geological Bureau

Kansas Geological Survey

Kentucky Geological Survey

Lamont-Doherty Geological Observatory of CoIumbia University

Lawrence Livermore National Laboratory

Los Alamos National Laboratory

Louisiana Geological Survey

Marathon Oil Company-Denver Research Center

Michigan Geological Survey

Minnesota Geological Survey

Missouri Division of Geology \& Land Survey

Mobil Research \& Developmient Corp. -Dallas Research Laboratory

National Institute for Petroleum \& Energy Research (NIPER)

National Snow and Ice Data Center (NSIDC)

Naval Research Laboratory

Nebraska Conservation \& Survey Division

Nevada Bureau of Mines \& Geology

New Jersey Geological Survey

New Mexco Bureau of Mines \& Mineral Resources

New Mexico Petroleum Recovery Research Center (PPRC)

-A Division of New Mexco Institute of Mining \& Technology

North Dakota Geological Survey

Ohio Division of Geological Survey

Oklahoma Geological Survey

Oregon Department of Geology \& Mineral Industries

Pennsylvania Bureau of Topographic \& Geological Survey

Phillips Petroleum Co. - Research \& Development

Reservoir Engineering Research Institute

Schlumberger-Doll Research Laboratory

Schlumberger-Houston Research Laboratory

Scripps Institution of Oceanography of University of California (San Diego)

Shell Development Company-Bellaire Research Center 
South Carolina Geologicval Survey

South Dakota Geological Survey

Southwest Research Institute (SRI)

Sun Exploration \& Production Company - Technology Center

Tennessee Division of Geology

TerraTek Drilling Research Laboratory

Texas Bureau of Economic Geology

Texaco Inc. - E\&P Technology Division

United States Geological Survey-National Center

United States Geological Survey-Federal Center

United States Geological Survey-EROS Data Center

United States Geological Survey-Menlo Park Regional Center

United States Geological Survey-Anchorage Field Center

United States Geological Survey-Vancouver Field Office

United States Geological Survey-Flagstaff Field Center

United States Geological Survey-Albuquerque Field Office

United States Geological Survey-Woods Hole Field Center

UNOCAL Corporation-Science \& Technology Division

Utah Geological and Mineral Survey

West Virginia Geological and Economic Survey

Wisconsin Geological \& Natural History Survey

Woods Hole Oceanographic Institution

Wyoming Geological Survey

U. S. S. R.

USSR Academy of Sciences-Moscow Headquarters - Institute of Geology (Moscow)

- Institute of Economic Geology, Petrology, Mineralogy \& Geochemistry (Mocsow)

- Institute of Lithosphere (Moscow)

- Shmidt Institute of Physics of the Earth (Moscow)

- Shirshov Institute of Oceanography (Moscow)

- Vernadskiy Institute of Geochemistry \& Analytical Chemistry (Moscow)

USSR Academy of Sciences-Leningrad Headquarters

USSR Academy of Sciences-Siberian Branch

-Institute of Geology \& Geophysics (Novosibirsk)

- Computer Center (Novosibirsk)

- Vinogradov Institute of Geochemistry (Irkutsk)

- Institute of the Earth's Crust (Irkutsk)

- Yakutsk Office (Yakutsk)

--Institute of Geology (Yakutsk)

- Buryay Office (Ulan-Ude)

-Institute of Geology (Ulan-Ude)

USSR Academy of Sciences-Ural Branch

- Institute of Geology \& Gephysucs (Sverdovsk)

- Ural Scientific Center (Sverdlovsk)

- Institute of Geology (Sverdlovsk)

-Zavaritskiy Institute of Geology \& Geochemistry (Sverdlovsk)

USSR Academy of Sciences-Bashkir Branch

-Institute of Geology (Ufa)

USSR Academy of Sciences-Far Eastern Branch
- Far Eastern Geological Institue (Vladivostok)

- Pacific Oceanographic Institute (Vladivostok)

- Institute of Tectonics \& Geophyscis (Khabarovsk)

- Far East Complex Scientific Reserach Institute (Magaden)

USSR Academy of Sciences - Kola Branch

- Institute of Geology (Apatity)

USSR Academy of Sciences-Shirshov Institute of Oceanography

- Atlantic Division (kaliningrad)

USSR Academy of Sciences - Chita Prospecting Institute

National Research Institute of Oil

GIPROVOSTOKNEET (State Institute of IndustryEastern Oil Research Center)

\section{GKNT}

Research Institute Neft

Institute of Geology \& Exploration of Combustible Fuels

West Siberian Oil-Prospection Institute

Azerbaijan Academy of Sciences-Gubkin Institute of Geology

Ukrainian Academy of Sciences

- Institute of Geological Sciences (Kiev)

- Institute of Gelogy \& Geochemistry of Fossil Fuels (L'vov)

- Institute of Geochemistry \& Physics of Minerals (Kiev)

- Marine Hydrophysical Institute (Sevastopol')

Turkmen Academy of Sciences - Institute of Engineering Physics

Ordzhonikidze Geological Prospecting Research Institute

Institute of Geophysical Methods of Ocean Exploration

Siberian Scientific Research Institute of Geology, Geophysics, and Mineral Resources

East Siberian Research Institute of Geology, Geophysdics \& Mineral Products

Northern Association for Marine Geophysical Exploration

Arctic and Antarctic Research Institute

Soyuzmorgeo Naval Scientific Production Organozation

Rudgeofizika Scientific Production Organization

Sibneftegeofizika Production Organization

Sibgeo Scientific Production Organization

Sevmorgeologiya Scientific Production Organization

Irkutsk Petrological Institute

AlI-Union Research Institute of Geology of Foreign Countries

All-Union Research Institute of Natutal Gas

All-Union Scientific Research Institute of Oceanography

All-Union Research Institute of Geology \& Mineral Resources of the Ocean

All-Union Institute of Nuclear Geophysics \& Geochemistry

Karapinskiy All-Union Geological Research Institute

VENEZUELA

Petroleos de Venezuela SA (PDVSA)-Research Center 